Short Communication

\title{
Genetic variability in five populations of Partamona helleri (Hymenoptera, Apidae) from Minas Gerais State, Brazil
}

\author{
Andreia Arantes Borges, Lucio Antônio de Oliveira Campos, Tânia Maria Fernandes Salomão \\ and Mara Garcia Tavares
}

Departamento de Biologia Geral, Universidade Federal de Viçosa, Viçosa, MG, Brazil.

\begin{abstract}
Partamona is a Neotropical genus of stingless bees that comprises 33 species distributed from Mexico to southern Brazil. These bees are well-adapted to anthropic environments and build their nests in several substrates. In this study, 66 colonies of Partamona helleri from five localities in the Brazilian state of Minas Gerais (São Miguel do Anta, Teixeiras, Porto Firme, Viçosa and Rio Vermelho) were analyzed using nine microsatellite loci in order to assess their genetic variability. Low levels of observed $\left(H_{o}=0.099-0.137\right)$ and expected $\left(H_{e}=0.128-0.145\right)$ heterozygosity were encountered and revealed discrete genetic differentiation among the populations $\left(F_{S T}=0.025\right)$. AMOVA further showed that most of the total genetic variation (94.24\%) in $P$. helleri was explained by the variability within local populations.
\end{abstract}

Key words: microsatellites, Partamona helleri, population genetics, stingless bees.

Received: January 22, 2010; Accepted: July 5, 2010.

Partamona is a Neotropical genus of stingless bees that comprises 33 species distributed from Mexico to southern Brazil (Pedro and Camargo, 2003). These bees are found in rain forests, savanna, caatinga and Andean highlands at altitudes greater than $2000 \mathrm{~m}$. Some species are well-adapted to anthropic environments and build their nests in a variety of substrates such as cavities and crevices in walls, among roots of epiphytes, in the bases of palm leaves, in abandoned bird nests, under bridges and in other protected sites; other species nest inside active terrestrial or arboreal termite nests (Camargo and Pedro, 2003).

Partamona species build notable nest entrance structures, with special surfaces for incoming/exiting bees. Some of these structures are extremely elaborate and ornamented, and serve as flight orientation targets. The number of individuals per nest ranges from 1000 to 3000 (Michener, 1946). The high abundance of individuals and colonies in several regions has facilitated studies of the genetic variability of populations of these bees. These studies have advanced with the development of molecular techniques such as microsatellites.

To date, microsatellite primers have been developed for eight species of stingless bees: Melipona bicolor (Peters et al., 1998), Scaptotrigona postica (Paxton et al., 1999), Trigona carbonaria (Green et al., 2001), M. rufiventris (Lopes et al., 2009), M. seminigra merrillae (Francini et

Send correspondence to Mara Garcia Tavares. Departamento de Biologia Geral, Universidade Federal de Viçosa, 36570-000 Viçosa, MG, Brazil. E-mail: mtavares@ufv.br. al., 2009), Tetragonisca angustula (Brito et al., 2009), Nannotrigona testaceicornis (Oliveira et al., 2009) and $M$. mondury (Lopes et al., 2010). Many of these primers generated PCR products when used to amplify microsatellite regions in DNA from other species of stingless bees, demonstrating that these markers can be used in populational studies (Paxton et al., 1999; Peters et al., 1999; Paxton, 2000; Cameron et al., 2004; Franck et al., 2004; Carvalho-Zilse and Kerr, 2006; Arias et al., 2006; Francisco et al., 2006; Tavares et al., 2007; Carvalho-Zilse et al., 2009). However, despite the availability of these markers, only two studies have examined the genetic variability of $P$. helleri (Brito, 2005; Francisco et al., 2006).

In the present study, microsatellite markers were used to estimate the number of alleles per locus, the observed heterozygosity and the degree of intra- and inter-populational genetic variation in $P$. helleri (Friese) collected in Viçosa (2045' S, 42 $52^{\prime}$ ' W; 19 colonies), Rio Vermelho (18 $17^{\prime} \mathrm{S}, 4^{\circ} 00^{\prime} \mathrm{W} ; 12$ colonies), Teixeiras $\left(20^{\circ} 39^{\prime} \mathrm{S}\right.$, $42^{\circ} 51^{\prime} \mathrm{W}$; 12 colonies), Porto Firme (20 $40^{\prime} \mathrm{S}, 43^{\circ} 05^{\prime} \mathrm{W}$; 11 colonies) and São Miguel do Anta (2042' S, 42 $43^{\prime}$ ' W; 12 colonies) in Minas Gerais state (Figure 1). Twenty adult workers were collected from feral colonies located different distances from each other, in rural and urban areas. The distances between colonies ranged from $5 \mathrm{~m}$ (six samples collected from the same wall in a residential area of Viçosa) to $18 \mathrm{~km}$ (three colonies collected in a rural area in Rio Vermelho). The remaining 13 colonies collected in Viçosa were 25-1000 $\mathrm{m}$ from each other while the distances sepa- 


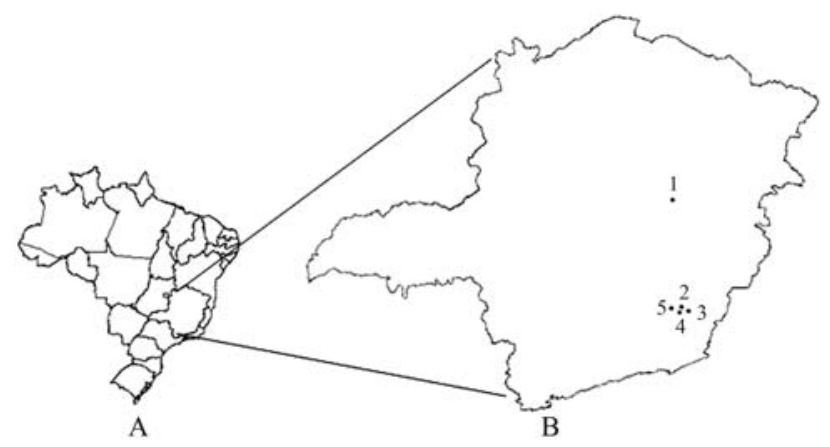

Figure 1 - Map of Brazil (A) and Minas Gerais state (B) showing the geographic location of the $P$. helleri populations analyzed: 1 - Rio Vermelho

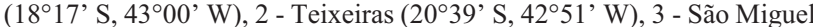
do Anta $\left(20^{\circ} 42^{\prime} \mathrm{S}, 42^{\circ} 43^{\prime} \mathrm{W}\right), 4$ - Viçosa $\left(20^{\circ} 45^{\prime} \mathrm{S}, 42^{\circ} 52^{\prime} \mathrm{W}\right)$ and 5 Porto Firme $\left(20^{\circ} 40^{\prime} \mathrm{S}, 43^{\circ} 05^{\prime} \mathrm{W}\right)$.

rating the nine remaining colonies collected in Rio Vermelho ranged from $15 \mathrm{~m}$ to $4 \mathrm{~km}$. At Teixeiras and Porto Firme the geographic distance between colonies varied from 85-500 m while colonies from São Miguel do Anta were 150-750 $\mathrm{m}$ apart.

The genomic DNA of five adult workers from each colony was extracted according to the protocol recommended by Waldschmidt et al. (1997). The amplification reactions consisted of a mixture of $10 \mu \mathrm{L}$ containing $0.1 \mathrm{mM}$ of each deoxyribonucleoside triphosphate (dATP, dCTP, dGTP, dTTP), $2.5 \mu \mathrm{M}$ of each primer, 0.5 unit of Taq polymerase (Phoneutria), $1 \mathrm{X}$ buffer containing $15 \mathrm{mM}$ $\mathrm{MgCl}_{2}$ and $10 \mathrm{ng}$ of DNA. The P. helleri DNA was amplified as reported by Brito (2005) and the amplification products were separated by electrophoresis in $8 \%$ non-denaturing polyacrylamide gels and visualized by staining with $0.2 \%$ silver nitrate.

The genetic variability in the populations was estimated from the analysis of nine microsatellite loci (Mbi11, 28, 32, 33, 201, 219, 254, 278 and 522) described for $M$. bicolor (Peters et al., 1998), using the following estimates: polymorphic locus percentage $(\mathrm{P})$, mean number of alleles/locus $\left(\mathrm{A}_{\mathrm{o}}\right)$ and observed $\left(\mathrm{H}_{\mathrm{o}}\right)$ and expected $\left(\mathrm{H}_{\mathrm{e}}\right)$ heterozygosities.

The genetic distance between populations was calculated using the Nei (1972) genetic distance as a dissimilarity measurement. The $F$ statistic (Wright, 1978) was used to analyze the genetic structure of the populations and analysis of molecular variance (AMOVA; Excoffier et al., 1992) was used to estimate the within and between population genetic variability. All of the statistical analyses were done using the Genes program (Cruz, 2009) with all of the colonies from the same locality being considered as a single population.

Of the nine loci analyzed in $P$. helleri, only two (Mbi254 and Mbi278) were polymorphic $(\mathrm{P}=22.22 \%)$. Locus Mbi254 generated 5-8 alleles in the different populations while locus Mbi278 generated two alleles in all popu- lations. The number of alleles observed for the Mbi254 locus in P. helleri (8) was greater than in M. bicolor (3), whereas five alleles were observed for the Mbi278 locus in M. bicolor (Peters et al., 1998). The number of alleles identified in P. helleri for the loci Mbi28, 201, 278 and 522 was identical to those reported by Francisco et al. (2006) for this same species.

Table 1 shows that the observed heterozygosity ranged from 0.099 (Porto Firme) to 0.137 (Rio Vermelho), with a mean of 0.122 . The lowest and highest expected heterozygosities were 0.128 and 0.145 for the Viçosa and Rio Vermelho populations, respectively, with a mean of 0.133 .

The mean observed heterozygosity for $P$. helleri $\left(\mathrm{H}_{\mathrm{o}}=0.122\right)$ was much lower than that reported for $M$. bicolor $\left(\mathrm{H}_{\mathrm{o}}=0.40\right)$ (Peters et al., 1998). Likewise, the mean heterozygosities for populations of Plebeia remota $\left(\mathrm{H}_{\mathrm{o}}=0.24\right)$ (Francisco et al., 2006), M. rufiventris $\left(\mathrm{H}_{\mathrm{o}}=0.07\right)$ and $M$. mondury $\left(\mathrm{H}_{\mathrm{o}}=0.12\right)$ (Tavares et al., 2007) were also lower than in M. bicolor, even when heterologous primers designed specifically for M. bicolor were used.

These data confirm that when heterologous primers are used the number of alleles and the heterozygosity values tend to be lower than in the species for which the microsatellite primers were developed (Peters et al., 1998; Paxton et al., 2003; Francisco et al., 2006; Souza et al., 2007). In addition, according to Carvalho-Zilse and Kerr (2006), the facultative polygyny of M. bicolor colonies may contribute to the greater genetic variability observed in this species compared to $P$. helleri, the colonies of which are headed by a single queen.

The genetic variability of Apis mellifera $($ Ho $=0.349-0.589)$ (De La Rúa et al., 2003) was higher than that of $P$. helleri. This difference may be explained by the multiple matings of honeybee queens that have an effective mate number of 12.4 (Estoup et al., 1994). In contrast, stingless bee queens generally mate once (Kerr et al., 1962; Da Silva et al., 1972; Contel and Kerr, 1976; Machado et al., 1984; Peters et al., 1999) and have an effective mate number of 1.06 (Strassmann, 2001). The estimated effective mate number of Partamona aff. cupira, a species closely related to $P$. helleri, is 0.91 (Peters et al., 1999).

Table 1 - Estimates of genetic parameters in five Partamona helleri populations. N: number of individuals sampled, $\mathrm{H}_{\mathrm{o}}$ : observed heterozygosity, $\mathrm{H}_{\mathrm{e}}$ : expected heterozygosity; $\mathrm{F}_{\mathrm{IS}}$ : fixation index.

\begin{tabular}{lcccc}
\hline Population & $\mathrm{N}$ & $\mathrm{H}_{\mathrm{o}}$ & $\mathrm{H}_{\mathrm{e}}$ & $\mathrm{F}_{\text {IS }}$ \\
\hline São Miguel do Anta & 12 & 0.127 & 0.129 & 0.018 \\
Teixeiras & 12 & 0.127 & 0.129 & 0.108 \\
Rio Vermelho & 12 & 0.137 & 0.145 & 0.128 \\
Porto Firme & 11 & 0.099 & 0.132 & 0.112 \\
Viçosa & 19 & 0.119 & 0.128 & 0.111 \\
\hline Mean & 13 & 0.122 & 0.133 & \\
\hline
\end{tabular}


The low level of genetic variability in $P$. helleri may also be explained by this species limited flight distance. The maximum flight distance for $P$. cupira is estimated to be 1159-1710 m (Araújo et al., 2004). Hence, it is reasonable to assume that, after swarming, new $P$. helleri colonies will not disperse more than $1700 \mathrm{~m}$ from their maternal colony. In addition, during swarming, the parental colony generally provides the new colonies with food and wax (Kerr, 1987), which further limits their spatial distribution. One consequence of this proximity between parental and daughter colonies is that different alleles may become fixed in adjoining spatial regions. In contrast, honeybees generally swarm over greater distances, with some studies indicating that swarms of Apis species may fly $90 \mathrm{~km}$ (Otis et al., 1981) to $110 \mathrm{~km}$ (Seeley, 1985) from the parental colony. The higher genetic variability of $A$. mellifera compared to $P$. helleri may explain its great adaptability to wide climatic variations and hence its greater ability to exploit different spatial habitats.

The ability of $P$. helleri to adapt to anthropic environments and to use a wide variety of substrates for nesting, together with the fact that many of the sampled colonies were located close to each other, suggests that the populations analyzed were derived from only a few parental colonies (few queens) that encountered favourable conditions for expansion. The establishing of new nests by the dispersing colony in the neighborhood of the parental colony probably led to a decrease in the genetic variability of the population. The artificial transport of $P$. helleri colonies between regions, which could increase the population genetic variability, is not a common practice among beekeepers, which do not rear this species commercially because of its aggressiveness and the low commercial value of its honey.

Nei's genetic distance calculated pairwise between populations varied from 0.00 to 0.0079 . These values were consistent with the geographic proximity of the sampled sites (except for Rio Vermelho), and with the fact that most of the alleles were shared by all of the populations. Indeed, the presence of an exclusive allele (allele $\mathrm{H}$ of the Mbi254 locus) was detected only in the population from Rio Vermelho, which is at least $270 \mathrm{~km}$ away from the other populations. All of the other alleles detected in the two polymorphic loci were present in at least two populations. The presence of this exclusive allele is evidence of restricted genetic flow between this and the other populations of $P$. helleri analyzed.

The presence of an exclusive allele may also indicate the existence of genetic structure among populations. In the present study, genetic structure was initially detected based on differences in the allelic frequencies among populations (data not shown) and further supported by the $\mathrm{F}_{\mathrm{IS}}$ (Table 1) and mean $\mathrm{F}_{S T}\left(\mathrm{~F}_{S T}=0.025\right)$ values. The $\mathrm{F}_{S T}$ value indicated that the genetic differentiation among the populations was discrete, whereas AMOVA showed that most (94.24\%) of the total genetic variation in $P$. helleri was explained by the genetic diversity within local populations, while $4.76 \%$ was distributed among the populations. Based on these findings, we suggest that there are genetic differences among the populations analyzed but that these differences are not great enough to classify the populations as separate subpopulations.

In conclusion, the populations of $P$. helleri analyzed here showed little genetic variability and genetic differentiation. This finding suggests that these populations originated from only a few colonies. However, additional studies are needed to improve our knowledge of the population dynamics and mode of colonization in this stingless bee.

\section{Acknowledgments}

This work was supported by the Brazilian agencies FAPEMIG and CNPq.

\section{References}

Araújo ED, Costa M, Chaud-Neto J and Fowler HG (2004) Body size and flight distance in stingless bees (Hymenoptera, Meliponini): Inference of flight range and possible ecological implications. Braz J Biol 64:563-568.

Arias MC, Brito RM, Francisco FO, Moretto G, Oliveira FF, Silvestre D and Sheppard WS (2006) Molecular markers as a tool for population and evolutionary studies of stingless bees. Apidologie 37:259-274.

Brito RM, Francisco FO, Domingues-Yamada AMT, Gonçalves PHP, Pioker FC, Soares AEE and Arias MC (2009) Characterization of microsatellite loci of Tetragonisca angustula (Hymenoptera, Apidae, Meliponini). Conserv Genet Resour 1:183-187.

Camargo JMF and Pedro SRM (2003) Meliponini neotropicais: O gênero Partamona Schwarz, 1939 (Hymenoptera, Apidae, Apinae). Rev Bras Entomol 47:311-372.

Cameron EC, Franck P and Oldroyd P (2004) Genetic structure of nest aggregations and drone congregations of the southeast Asian stingless bee Trigona collina. Mol Ecol 13:23572364.

Carvalho-Zilse GA and Kerr WE (2006) Utilização de marcadores microssatélites para estudos populacionais em Melipona scutellaris (Apidae, Meliponini). Magistra 18:213220.

Carvalho-Zilse GA, Costa-Pinto MFF, Nunes-Silva CG and Kerr WE (2009) Does beekeeping reduce genetic variability in Melipona scutellaris (Apidae, Meliponini)? Genet Mol Res 8:758-765.

Contel EPB and Kerr WE (1976) Origin of males in Melipona subnitida estimated from data of an isozymic polymorphic system. Genetica 46:271-277.

Da Silva DLN, Zucchi R and Kerr WE (1972) Biological and behavioral aspects of the reproduction in some species of Melipona (Hymenoptera, Apidae, Meliponinae). Anim Behav 20:123-131.

De La Rúa P, Galián J, Serrano J and Moritz FA (2003) Genetic structure of Balearic honeybee populations based on microsatellite polymorphism. Genet Sel Evol 35:339-350. 
Estoup A, Solignac M and Cornuet JM (1994) Precise assessment of the number of patrilines and of genetic relatedness in honeybee colonies. Proc R Soc Lond B 258:1-7.

Excoffier L, Smouse PE and Quattro JM (1992) Analysis of molecular variance inferred from metric distances among DNA haplotypes: Application to human mitochondrial DNA restriction data. Genetics 131:479-491.

Francini IB, Sforça DA, Sousa ACB, Campos T, Cidade FW, Zucchi MI, Souza AP, Nunes-Silva CG and Carvalho-Zilse GA (2009) Microsatellite loci for an endemic stingless bee Melipona seminigra merrilae (Apidae, Meliponini) from Amazon. Conserv Genet Resour 1:487-490.

Francisco FO, Brito RM and Arias MC (2006) Allele number and heterozygosity for microsatellite loci in different stingless bee species (Hymenoptera, Apidae, Meliponini). Neotrop Entomol 35:638-643.

Franck P, Cameron E, Good G, Rasplus jy and Oldroyd bp (2004) Nest architecture and genetic differentiation in a species complex of Australian stingless bees. Mol Ecol 13:23172331.

Green CL, Franck P and Oldroyd P (2001) Characterization of microsatellite loci for Trigona carbonaria, a stingless bee endemic to Australia. Mol Ecol 1:89-92.

Kerr WE (1987) Abelhas indígenas brasileiras (meliponíneos) na polinização e na produção de mel, pólen, geoprópolis e cera. Inf Agropec 149:15-22.

Kerr WE, Zucchi R, Nakadaira JT and Butolo JE (1962) Reproduction in the social bees (Hymenoptera, Apidae). J N Y Entomol Soc 70:265-276.

Lopes DM, Silva FO, Salomão TMF, Campos LAO and Tavares MG (2009) Microsatellite loci for the stingless bee Melipona rufiventris (Hymenoptera, Apidae). Mol Ecol Resour 9:923-925.

Lopes DM, Silva FO, Salomão TMF, Campos LAO and Tavares MG (2010) A scientific note on the characterization of microsatellite loci for Melipona mondury (Hymenoptera, Apidae). Apidologie 41:138-140.

Machado MFPS, Contel EPB and Kerr WE (1984) Proportion of males sons-of-the-queen and sons-of-workers in Plebeia droryana (Hymenoptera, Apidae) estimated from data of an MDH isozymic polymorphic system. Genetica 65:193-198.

Michener CD (1946) Notes on the habits of some Panamanian stingless bees (Hymenoptera, Apidae). J N Y Entomol Soc 54:179-197.

Nei M (1972) Genetic distance between populations. Am Nat 106:283-292.

Oliveira EJF, Freitas GS, Fonseca AS, Sousa ACB, Campos T, Assis AF, Souza AP, Contel EPB and Soares AEE (2009) Isolation and characterization of microsatellite markers from the stingless bee Nannotrigona testaceicornis. Conserv Genet Resour 1:97-99.

Otis GW, Winston ML and Taylor OR (1981) Engorgement and dispersal of Africanized honeybee swarms. J Apic Res 20:3-12.
Paxton RJ (2000) Genetic structure of colonies and a male aggregation in the stingless bee Scaptotrigona postica, as revealed by microsatellites analysis. Insectes Soc 47:63-69.

Paxton RJ, Weißschuh N, Engels W and Quezada-Euán JJG (1999) Characterization of dinucleotide microsatellite locos for stingless bees. Mol Ecol 8:685-702.

Paxton RJ, Bego LR and Shah MM (2003) Low mating frequency of queens in the stingless bee Scaptotrigona postica and worker maternity of males. Behav Ecol Sociobiol 53:174181.

Pedro SRM and Camargo JMF (2003) Meliponini Neotropicais: O gênero Partamona Schwarz, 1939 (Hymenoptera, Apidae). Rev Bras Entomol 47:1-117.

Peters JM, Queller DC, Imperatriz-Fonseca VL and Strassmann JE (1998) Microsatellite loci for stingless bees. Mol Ecol 7:783-792.

Peters JM, Queller DC, Imperatriz-Fonseca VL, Roubik DW and Strassmann JE (1999) Mate number, kin selection and social conflicts in stingless bees and honeybees. Proc R Soc Lond B 266:379-384.

Seeley TD (1985) Honeybee Ecology: A Study of Adaptation in Social Life. Princeton University Press, Princeton, 201 pp.

Souza RO, Cervini M, Del Lama MA and Paxton RJ (2007) Microsatellite loci for euglossine bees (Hymenoptera, Apidae). Mol Ecol Notes 7:1352-1356.

Strassmann J (2001) The rarity of multiple mating by females in the social Hymenoptera. Insectes Soc 48:1-13.

Tavares MG, Dias LAS, Borges AA, Lopes DM, Busse AHP, Costa RG, Salomão TMF and Campos LAO (2007) Genetic divergence between populations of the stingless bee uruçu amarela (Melipona rufiventris group, Hymenoptera, Meliponini): Is there a new Melipona species in the Brazilian state of Minas Gerais? Genet Mol Biol 30:667-675.

Waldschmidt AM, Salomão TMF, Barros EG and Campos LAO (1997) Extraction of genomic DNA from Melipona quadrifasciata (Hymenoptera, Apidae, Meliponinae). Braz J Genet 20:421-423.

Wright S (1978) Evolution and the Genetics of Populations. Variability Within and Among Natural Populations. University of Chicago Press, Chicago, 590 pp.

\section{Internet Resources}

Brito RM (2005) Análise molecular e populacional de Partamona mulata (Moure in Camargo, 1980) e Partamona helleri (Friese, 1900) (Hymenoptera, Apidae, Meliponini). Doctoral Thesis. Universidade de São Paulo, 189 pp, http://www.teses.usp.br/teses/disponiveis/41/41131/tde-04 012006-120045/ (January 5, 2010).

Cruz CD (2009) Programa Genes: Aplicativo Computacional em Genética e Estatística. Versão Windows. http:// www.ufv.br/dbg/genes/genes.htm.

\section{Associate Editor: Fábio de Melo Sene}

License information: This is an open-access article distributed under the terms of the Creative Commons Attribution License, which permits unrestricted use, distribution, and reproduction in any medium, provided the original work is properly cited. 